\title{
Notes on historical aspects on the earliest known observations of noctilucent clouds
}

\author{
P. Dalin ${ }^{1,2}$, N. Pertsev ${ }^{3}$, and V. Romejko ${ }^{4}$ \\ ${ }^{1}$ Swedish Institute of Space Physics, P.O. Box 812, 98128 Kiruna, Sweden \\ ${ }^{2}$ Space Research Institute, RAS, Profsouznaya st. 84/32, Moscow 117997, Russia \\ ${ }^{3}$ A.M. Obukhov Institute of Atmospheric Physics, RAS, Pyzhevskiy per., 3, Moscow 119017, Russia \\ ${ }^{4}$ The Moscow Association for NLC Research, Kosygina st. 17, 119334 Moscow, Russia \\ Correspondence to: P. Dalin (pdalin@irf.se)
}

Received: 22 September 2011 - Revised: 15 February 2012 - Accepted: 9 March 2012 - Published: 27 March 2012

\begin{abstract}
The present paper considers historical aspects of the earliest known observations of noctilucent clouds (NLCs). The 1884 and 1885 are discussed by considering important historical citations by the pioneers of the earliest known observations of noctilucent clouds. For the first time in NLC studies, we consider seven major volcanic eruptions: Laki in 1783, Mount St. Helens in 1800, Tambora in 1815, Galunggung in 1822, Cosigüina in 1835, Shiveluch in 1854 and Askja in 1875. These all preceded the catastrophic 1883 eruption of Krakatoa, which despite having a lesser magnitude than Tambora in 1815, had pronounced effects on the atmosphere. These eruptions represent possible triggers for the appearance of NLCs. For the first time, we publish an unknown, in English-speaking literature, historical fact on the first determinations of the altitude of noctilucent clouds made by two Russian astronomers V. K. Tseraskii and A. A. Belopolskii on 26 June 1885, who managed to infer the altitude of the clouds in the range of $73-83 \mathrm{~km}$, that is, for the first time, demonstrating the possible existence of the clouds at great altitudes in the Earth's atmosphere. Moreover, V. K. Tseraskii was the first observer to photograph noctilucent clouds in 1885 or 1886, which is $1-2 \mathrm{yr}$ before the German astronomer O. Jesse, who owns the first published images of noctilucent clouds. The photographs made by V. K. Tseraskii, unfortunately, did not reach us.
\end{abstract}

\section{Introduction}

Noctilucent clouds (NLCs), or night luminous clouds, are the highest clouds in the Earth's atmosphere, occurring in the mesopause at an altitude range of $80-85 \mathrm{~km}$. These silvery-bluish clouds express a brilliant night-time optical phenomenon during the summer months at mid- and high latitudes. The visible structure of NLCs is similar to cirrus clouds, but the former show more intensive and complex structures with signatures of turbulent vortices and waves of different scales. Noctilucent clouds are composed of water ice crystals of $30-100 \mathrm{~nm}$ in radius that scatter a sufficient amount of sunlight and thus NLCs are readily seen against the dark twilight sky from May until September (Gadsden and Schröder, 1989).

The history of the first observations of NLCs is well described in the canonical books by Bronsten and Grishin (1970) and by Gadsden and Schröder (1989), and we refer the interested reader to these sources (and therein references). The purpose of the present paper is to address spe- cific issues that have been missed in the literature on noctilucent clouds: (1) atmospheric impact of the major volcanic eruptions during the period of 1783-1883; (2) the year of the earliest known observations; (3) the earliest photographic registrations and height estimations of noctilucent clouds.

In recent publications (Taylor et al., 2002; Hartquist et al., 2009; Pautet et al., 2011) a new year of 1884 of the discovery of noctilucent clouds was established. Under the term "discovery" we mean the earliest known observations of NLCs, realizing at the same time that NLCs could be observed before their first well-established appearances in the summer of 1885 (Fogle and Haurwitz, 1966; Bronsten and Grinshin, 1970; Gadsden and Schröder, 1989). In the present paper we make comments which, in our opinion, are important when revising the date of the well-established historical event. Probably, the most correct way is to refer to the pioneers of the first NLC observations as well as to those authors who made great efforts in historical studies of the considered atmospheric phenomena. 
We report on previously unpublished, in the literature concerning NLC studies, major volcanic eruptions, preceding the catastrophic 1883 Krakatoa eruption, which could have influenced not only the lower atmosphere but also on the middle atmosphere, thus likely fostering the NLC formation prior to the year of the discovery of bright and extended NLCs in 1885. In addition, we limited our study to regarding the volcanic activity from 1783 until 1883 , which is the time interval before the great Krakatoa eruption and not too far from this event, in the hope that it will be possible, for other researchers, to find interesting notes on atmospheric phenomena similar to night luminous clouds in astronomical archives for a relatively modern epoch.

\section{Was the Krakatoa eruption the only trigger for noctilucent clouds?}

It is worth examining the circumstances associated with the start of occurrences of noctilucent clouds that are not marked in any work on the history of NLC. It is believed that the most likely trigger of the NLC origin was a huge volcanic eruption in August of 1883, located on Krakatoa Island between the islands of Sumatra and Java in the Indonesian archipelago. This disaster had terrible consequences on the people of Indonesia, a massive tsunami killed about 36000 people and two-thirds of the island was destroyed and sank into the sea. The eruption led to abnormally colored twilight skies and optical disturbances over the northern hemisphere (Verbeek, 1884; Gadsden and Schröder, 1989).

Although the Krakatoa eruption of 1883 is probably the best known of all explosive volcanic eruptions to volcanologists, fundamental characteristics of this catastrophe such as the height of the eruption plume, the total erupted mass and the mass eruption rate are still poorly known (Sigurdsson et al., 1990). According to modern studies based on eruptive dynamics, the most likely altitude of the eruption column was about $40-50 \mathrm{~km}$ and the volumes of the ejected nearsource volcanic material and of distal ash fall were equal to about $12 \mathrm{~km}^{3}$ and $8.5 \mathrm{~km}^{3}$, respectively. These results are based, firstly, on detailed field studies of the deposits around volcano, stratigraphy of the tephra, aerial photography, and, secondly, on model studies of pyroclast dispersal which allow to infer information on the parameters of the eruption intensity (Carey and Sparks, 1986; Self and Rampino 1981; Rampino and Self, 1982). Thomas et al. (1989) have estimated a total water mass was of about $100-200 \mathrm{Mt}$, injected into the middle and upper atmosphere, which, together with huge amount of condensation nuclei, provided enormous changes in the summer mesopause environment which, in turn, led to abrupt bright NLC occurrences in 1885; the authors pointed out that "... before 1885 there was insufficient water vapour routinely available at the mesopause to form visible clouds...". The authors performed model studies, made with one-dimensional model developed by Jensen and Thomas (1988), which involve additional information on the increase of atmospheric methane which oxidizes above $30 \mathrm{~km}$, producing significant additional amounts of water vapor in the mesosphere. The authors calculated the evolution of the NLC brightness on the scale from 1840 to 2040, finding a threshold year of 1885 after which NLC could be visually seen with brightness exceeding the brightness of the twilight sky.

It was surprising to us to learn that the Krakatoa eruption was not the only eruption that occurred in 1883. The literature describing the earliest known observations of NLCs and the Krakatoa eruption do not refer to any other volcano that year. However, it is well-known in volcanological society that a significant eruption of the Augustine volcano in southern Alaska occurred on 6 October 1883 (Newhall and Self, 1982). This eruption is ranked as 4 on a scale called the Volcanic Explosivity Index (VEI) (see below). Note that the latitude of Augustine is $59.4^{\circ} \mathrm{N}$, and hence the emitted water vapor and aerosol particles could directly transfer into the polar middle atmosphere, without being meridionally transported from the equatorial regions. Thus, the 1883 Augustine eruption could contribute to the total $\mathrm{H}_{2} \mathrm{O}$ /aerosol loading of the polar mesosphere together with the great Krakatoa event of the same year.

In general, the relationship between NLCs and volcanic eruptions is unclear due to the absence of reliable model calculations and measurements on the transport of water vapor and aerosols to the mesopause altitude of $85 \mathrm{~km}$, and due to poor statistical analysis so far. After some eruptions (Krakatoa in 1883, Bezymianny in 1956, Agung in 1963) there was an increase in the NLC activity, but other volcanic events (Okataina in 1886, Mount Pelée and Santa Maria in 1902, Tarumai in 1909, Taal in 1911, Katmai in 1912) did not result in increased NLC activity. Summarizing, Fogle and Haurwitz (1973) concluded: "We are well aware that our suggestion concerning the role of volcanic eruption of the Plinian type in the enhancement of noctilucent cloud activity is based at present on weak and partly even conflicting evidence and, as far as the atmospheric circulation is concerned, largely on surmise". At the same time, it is a well-known fact in volcanological society that the catastrophic Krakatoa eruption was not the most powerful in recorded history.

It is worth noting that the most prevalent volcanic gas typically released into the atmosphere is water vapor, followed by carbon dioxide and sulfur dioxide. For different types of volcanoes, the volume concentration of injected $\mathrm{H}_{2} \mathrm{O}$ varies from 37 to $97 \%$ (Symonds et al., 1994). Plinian eruptions are characterized by columns of gas and volcanic ash extending high into the stratosphere, more than $10 \mathrm{~km}$ altitude. Water vapour and ash slowly ascend to sub-polar and polar regions (due to wave dynamic coupling between the stratosphere and mesosphere as well as owing to vertical transport being part of the interhemispheric atmospheric circulation, Becker and Schmitz, 2003) into the middle atmosphere, favouring the formation of noctilucent clouds. However, the exact amount 
Table 1. The great eruptions occurred from 1783 to 1883 with a VEI equal to or more than 4+. Exception is given for the Augustine eruption with VEI equal to 4 to demonstrate the complexity of the volcanic activity in 1883. After Newhall and Self (1982), Zielinski et al. (1994), Cole-Dai et al. (2009) and Siebert et al. (2010).

\begin{tabular}{|c|c|c|c|c|}
\hline Name & Location & Date & VEI & Type of eruption \\
\hline Laki (Lakagigar) & $\begin{array}{l}\text { Iceland } \\
64.1^{\circ} \mathrm{N} 18.3^{\circ} \mathrm{W}\end{array}$ & $1783-06-08$ & $4+$ & Strombolian and subplinian \\
\hline Mount St. Helens & $\begin{array}{l}\text { Washington, USA } \\
46.2^{\circ} \mathrm{N} 122.2^{\circ} \mathrm{W}\end{array}$ & 1800 & 5 & Plinian \\
\hline Tambora & $\begin{array}{l}\text { Sumbawa Island } \\
\text { (Indonesia) } \\
8.3^{\circ} \mathrm{S} 118.0^{\circ} \mathrm{E}\end{array}$ & $\begin{array}{l}1809 \\
1815-04-10\end{array}$ & $\begin{array}{l}? \\
7\end{array}$ & $\begin{array}{l}\text { ? Undocumented eruption } \\
\text { Ultra-Plinian }\end{array}$ \\
\hline Galunggung & $\begin{array}{l}\text { Java (Indonesia) } \\
7.3^{\circ} \mathrm{S} 108.1^{\circ} \mathrm{E}\end{array}$ & $1822-10-08$ & 5 & Plinian \\
\hline Cosigüina & $\begin{array}{l}\text { Nicaragua } \\
13.0^{\circ} \mathrm{N} 87.6^{\circ} \mathrm{W}\end{array}$ & $1835-01-20$ & 5 & Plinian \\
\hline Shiveluch & $\begin{array}{l}\text { Kamchatka } \\
56.8^{\circ} \mathrm{N} 161.6^{\circ} \mathrm{E}\end{array}$ & $1854-02-18$ & 5 & Plinian \\
\hline Askja & $\begin{array}{l}\text { Iceland } \\
65.0^{\circ} \mathrm{N} 16.8^{\circ} \mathrm{W}\end{array}$ & $1875-03-29$ & 5 & $\begin{array}{l}\text { Subplinian, phreatoplinian, } \\
\text { Plinian }\end{array}$ \\
\hline Krakatoa & $\begin{array}{l}\text { Indonesia } \\
6.1^{\circ} \mathrm{S} 105.4^{\circ} \mathrm{E}\end{array}$ & $1883-08-26$ & 6 & Plinian \\
\hline Augustine & $\begin{array}{l}\text { Southern Alaska } \\
59.4^{\circ} \mathrm{N} 153.4^{\circ} \mathrm{W}\end{array}$ & $1883-10-06$ & 4 & Subplinian \\
\hline
\end{tabular}

of water vapor ejected into the stratosphere, which reaches the mesopause altitude following a given explosive eruption, is an unknown quantity so far.

Nowadays, a volcanic eruption is classified by the Volcanic Explosivity Index (VEI) that describes the magnitude of an explosive volcanic eruption. VEI is analogous to the Richter magnitude scale for earthquakes. The VEI scale extends from 0 to 8 marks, representing a logarithmic scale in which an increase of 1 unit corresponds to an increase of intensity of a factor of 10 . VEI includes the following eruption characteristics: total volume of explosive products, height of eruptive cloud above the vent, eruption type, duration of continuous blast, extent of tropospheric and stratospheric injection and some other descriptive characteristics. The VEI scale was developed by Newhall and Self (1982), and updated data are presented in Siebert et al. (2010).

The 1883 Krakatoa eruption has a VEI of 6 marks. We have selected the great volcanic eruptions with a VEI of equal to or more than 4+, that is, according to Siebert et al. (2010), having significant stratospheric injection and pronounced atmospheric disturbances, at least on regional scales. Some of the below described eruptions had significant impact on the lower atmosphere on a global scale. We could not find in the literature concerning the NLC studies any mention of these great events that occurred relatively close in time to the Krakatoa eruption. In our opinion, it is important to consider these events since they had similar terrible consequences on people and pronounced effects on the atmosphere. The eruptions are presented in chronological order and their main characteristics are summarized in Table 1.
The Laki/Lakagigar eruption $(\mathrm{VEI}=4+$ ) occurred in the south of Iceland on 8 June 1783. 130 craters opened, representing a $27-\mathrm{km}$-long fissure system, with explosions due to interaction of the groundwater with the rising basalt magma. The eruptions lasted for eight months during 1883 to 1884 . About $15 \mathrm{~km}^{3}$ of basalt lava were ejected by the eruption. Lava fountains reached heights of 800-1400 m, and the eruption columns of gases and ash rose to altitudes of about 9-13 km, expressing the Strombolian and subplinian type (Thordarson and Self, 2003). The fire fountains of Laki were seen from several locations in the south of Iceland (Stephenson, 1783; Björnsson 1783; Steingrímsson and Ólafsson, 1783; Thorarinsson, 1783). Based on the locations of witnesses the researchers have estimated the observed height of the fire fountains and eruption column, which agree well with the independent estimates of eruption column heights made with model calculations based on the eruptive dynamics (Thordarson and Self, 1993). A wealth of citations from the records of the eyewitnesses of the Laki haze and optical effects can be found in Thordarson and Self (2003). The released water vapor dominated over other gas components and contributed as much as $235 \mathrm{Mt}$ (Thordarson et al., 1996). Due to ash fall, the 1783 summer was called as the "sand-summer" and "Laki haze" in Europe, and in Icelandic chronicles it is known as the "Haze Famine". Extreme summer and winter weather in Europe in successive years resulted in bad harvests and severe famine. The successive eight-month emission of sulfuric aerosols led to one of the most socially and environmentally terrible periods of the last millennium (Wood, 1992). Unusual weather and optical 
phenomena were noted in Europe and North America by famous contemporaries such as Gilbert White, Sir John Cullum and Benjamin Franklin. In particular, American scientist and diplomat B. Franklin described the unusual weather conditions in his lecture in 1784: "During several of the summer months of the year 1783, when the effect of the sun's rays to heat the earth in these northern regions should have been greater, there existed a constant fog over all Europe, and a great part of North America. ... Hence the surface was early frozen. Hence the first snows remained on it unmelted, and received continual additions. Hence the air was more chilled, and the winds more severely cold. Hence perhaps the winter of 1783-4 was more severe than any that had happened for many years."

The great eruption of the Mount St. Helens volcano $(\mathrm{VEI}=5)$ occurred between October 1799 and May 1800, located in Washington State, in the Pacific Northwest region of the United States. The peak eruption height was about $16 \mathrm{~km}$, with an erupted tephra volume of about $1.5 \mathrm{~km}^{3}$. The eruption was characterized by the explosive Plinian phase, followed by several minor explosions (Crandell et al., 1975; Yamaguchi, 1983; Carey et al., 1995; Siebert et al., 2010). The eruptive characteristics have been estimated based on detailed field investigations of fall deposits, dispersal of lithic clasts, and have been derived from theoretical models of tephra dispersal which are capable of calculating eruption column height, magma discharge and wind velocity from dispersal characteristics of fall deposits (Mullineaux, 1986; Carey and Sparks, 1986; Wilson and Walker, 1987).

The cataclysmic Tambora eruption $(\mathrm{VEI}=7)$ occurred on Sumbawa Island in Indonesia in April of 1815; this is the most powerful eruption in recorded history (Stewart, 1820; Zollinger, 1855; Sigurdsson and Carey, 1989; Oppenheimer, 2003). VEI equal to 7 means about ten times greater magnitude than the 1883 Krakatoa eruption. A moderately large explosive eruption occurred on 5 April 1815, from which ash fell in east Java and thunder-like sounds were heard up to $2600 \mathrm{~km}$ away. A larger eruption occurred on 10-11 April, beginning as "three columns of fire rising to a great height" (Raffles, 1830; Zollinger, 1855), ejecting about $50 \mathrm{~km}^{3}$ of magma, that is about 4-5 times more than ejected material from the Krakatoa eruption. Crandell et al. (1975) concluded that the 1815 Tambora eruption "... was one of the most voluminous (if not the most voluminous) explosive eruptions of historic time." More than 71000 people living in the Indonesian archipelago perished. Earthquakes were felt as far as $500 \mathrm{~km}$ away. The eruptions were of the Ultra-Plinian type and lofted gases and ash to an altitude of more than $43 \mathrm{~km}$ (Oppenheimer, 2003). The Tambora disaster caused a global climate anomaly called "volcanic winter", and ash lowered the average global temperature by as much as 0.4 $0.7^{\circ} \mathrm{C}$, with surface temperature anomalies of $-0.51,-0.44$ and $-0.29^{\circ} \mathrm{C}$ during the summers of 1816,1817 and 1818 , respectively (Stothers, 1984; Briffa et al., 1998). The year after the eruption, 1816, is a well-known historical event called
"The Year Without a Summer". Optical phenomena, colored sunsets and twilights were frequently seen in Europe. The sequences of this extraordinary event were reflected in the paintings of J. M. W. Turner as well as motivating the famous British authors Mary Shelley, John William Polidori and Lord Byron to write their legendary novel, story and poem "Frankenstein; or, The Modern Prometheus", "The Vampyre" and "Darkness", respectively (Sunstein, 1991). The bad weather conditions that occurred in the summer of 1816, when Mary Shelley was writing her novel, were clearly described in the preface and introduction to "Frankenstein; or, The Modern Prometheus", 1831 edition (Shelley, 1831).

However, it seems that the 1815 catastrophic eruption of Tambora was not alone responsible for the abnormal coldest decade in 1810-1819 during the past $500 \mathrm{yr}$. Zielinski et al. (1994) have discovered high concentrations of the $\mathrm{SO}_{4}^{2-}$ sulfate ion in the GISP2 Greenland ice core for the 1809 layer. Note that $\mathrm{SO}_{4}^{2-}$ is a direct product of the $\mathrm{H}_{2} \mathrm{SO}_{4}$ volcanic aerosol, the last one having significant climatic impact due to its high albedo. Cole-Dai et al. (2009) have confirmed this result and unambiguously showed that there was another, undocumented, powerful eruption in the tropics (it might be Tambora as well) in the beginning of 1809. Their result is based on careful analysis of the sulfur isotope anomaly $\Delta^{33} \mathrm{~S}$ of volcanic sulfuric acid produced in the stratosphere, which then further meridionally transports to the poles and is preserved in the polar ice of Greenland and Antarctica. The authors demonstrated similar deposition characteristics both in timing and flux values of the $\Delta^{33} \mathrm{~S}$ anomaly of the 1809 volcanic sulfate in polar ice core samples. They also found a period of about 18 months is required for stratospheric volcanic aerosols to be meridionally transported from the tropics and deposited at the poles.

In this light, it is interesting to mention the great Russian poet Alexander Pushkin. He wrote in his poetry "Recollections in Tsarskoe Selo":
A gloomy night became a veil for sleeping heaven, A dale and groves keep silence in their dreams,
There is a wood in grizzled mist and
Gentle voice of stream, which running to the oaks shadow,
The breeze is slightly breathing in the bed of leaves,
And serene Moon - majestic swan,
Is swimming through the silvery clouds.
It swims and suddenly,
Its pale light illumes the landscape,
Discovering for eyes the alley of old lindens,
And hills and meadow come partly into view.

October 1814

Translated by Tamara Rodzinskaya

The four last lines are very important for understanding of the described picture. They were not included in the 
final version of the poem by A. Pushkin, these lines were published after his death as an early version. "Is swimming through the silvery clouds" - an amazingly realistic metaphor of the great 15-yr-old poet, is it not? Or is it not a metaphor? In spite of the fact that this poem was written by A. Pushkin in October of 1814, the author clearly describes summer conditions: "... Gentle voice of stream, which running to the oaks shadow, The breeze is slightly breathing in the bed of leaves,...". Also, the author introduces nighttime: "A gloomy night became a veil for sleeping heaven, A dale and groves keep silence in their dreams...". At the same time, we can find an indication on the presence of the Moon behind tropospheric clouds: "It swims and suddenly, its pale light illumes the landscape...". It is also readily possible, due to the fact that noctilucent and tropospheric clouds are often seen together in the twilight sky, that sometimes thick tropospheric clouds can totally eclipse both the Moon and noctilucent clouds. When tropospheric clouds are gone, bright moonlight as well as bright noctilucent clouds can light up the observer's landscape. But the key point of the above mentioned passage is the term "silvery clouds". In the Russian language, this term spells as "серебристые облака (serebristye oblaka)", literally meaning the modern official title of noctilucent clouds in Russian scientific literature. Besides, A. Pushkin lived in Tsarskoe Selo (close to St. Petersburg), when was writing his poem, which is located at the high latitude of $59.7^{\circ}$ N. Furthermore, A. Pushkin continuously stayed in Tsarskoe Selo during the period of 18111814 , thus, it is possible that he combined his impressions of several summer weather conditions, observed for different years, into a single natural picture described in his poem. Thus, we find four important issues in the passage, intrinsic to noctilucent clouds: (1) silvery clouds, (2) night time, (3) summer conditions, and (4) the observational site located at high latitude. Another interesting issue is given by the author, namely, the position of the Moon placed in the area of noctilucent clouds. We managed to find a wonderful photograph (see Fig. 1) taken by V. Romejko supporting a principal possibility of observing the Moon directly inside the field of noctilucent clouds in the second half of summer at high latitudes. Thus, A. Pushkin could readily observe noctilucent clouds in the second half of the summers of 1811-1814, that is $28-31 \mathrm{yr}$ after the Laki disaster, 11-14 yr since the Mount St. Helens eruption, and 2-5 yr since the undocumented powerful eruption in the tropics in 1809. Nevertheless, the doubts must be kept in mind: A. Pushkin could allegorically call ordinary tropospheric clouds as "silvery clouds", in which the Moon was swimming and was suddenly shining brighter when tropospheric clouds were gone.

The large eruption of the Galunggung volcano $(\mathrm{VEI}=5)$ occurred on 8 October 1822 on Java Island (Indonesia). The 1822 eruption was of the explosive type, ejected more than $1 \mathrm{~km}^{3}$ of tephra, and produced pyroclastic flows, mudflows as well as lava dome extrusion. The eruption lasted about 50 days and killed over 4000 people (Siebert et al., 2010).

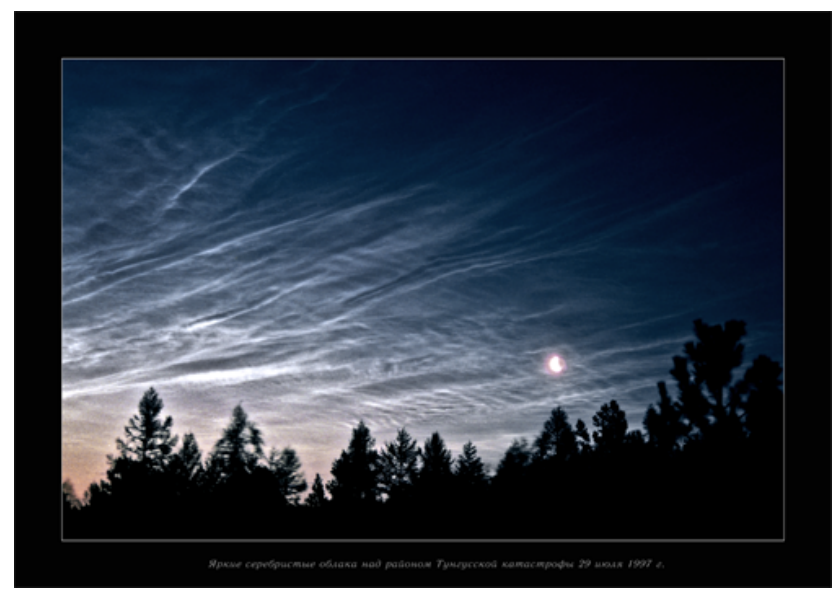

Figure 1. "And serene Moon - majestic swan, Is swimming through the silvery clouds." Photographed by V. Romejko on 29 July 1997, Tunguska region in Siberia, latitude is $60.9^{\circ} \mathrm{N}$.

The explosive eruption of the Cosigüina volcano (VEI = 5) occurred on 20 January 1835 in Nicaragua and it was the country's largest eruption in recorded history. The eruption was of the Plinian type and threw out a column to the height of 25-28 km (Self et al., 1989). The duration of the eruption was just a few days but the eruption was powerful, ejecting a large volume of tephra of more than $1 \mathrm{~km}^{3}$. The eruption was accompanied by pyroclastic flows which reached the Gulf of Fonseca. Ashfall was registered as far away as Mexico $(600 \mathrm{~km})$, Costa Rica $(350 \mathrm{~km})$ and Jamaica $(1300 \mathrm{~km})$ (Siebert et al., 2010). Soldiers in Guatemala had imagined that an artillery attack had begun. The noise from the eruption was heard in Mexico, Jamaica and Bogotá (Galindo, 1835a, b; Williams, 1952; Scott et al., 2006).

A violent explosive eruption of the Plinian type of the Shiveluch volcano $(\mathrm{VEI}=5)$ occurred on 17-18 February 1854 on the Kamchatka Peninsula (Russia). This eruption is considered to be climatically effective, at least on regional scales, with high amounts of $\mathrm{SO}_{4}^{2-}$ deposition for 1854, recorded in the Greenland ice core (Zielinski et al., 1994; Braitseva et al., 1997; Solomina et al., 2008). The eruption was accompanied by the failure of the volcano summit, extensive lava flows on all volcano slopes, destruction of forest at the base of the volcano by enormous stones and the ice breaking on the Elovka and Kamchatka rivers. The volume of ejected tephra was equal to about $1 \mathrm{~km}^{3}$. Also, ashfall was found as far as about $45 \mathrm{~km}$ south of the volcano, in Kliuchi, and about $200 \mathrm{~km}$ northwest of the volcano, Tigil' (Meniailov, 1955; Gorshkov and Dubik, 1970; Ponomareva et al., 1998). Gorshkov and Dubik (1970) concluded that "In the whole the eruption in 1854 was more powerful than the eruption in 1964 and it is compared with the Bezymianny volcano eruption in 1956 and probably it was even more powerful." Note that the latter eruption has a VEI of 5 marks (Newhall and Self, 1982; Siebert et al., 2010). 
The Askja eruption occurred on 1 January 1875 in northeastern Iceland. The Askja volcano is represented by the $100 \mathrm{~km}$-long fissure swarm. This eruption was one of the most powerful eruptions in Icelandic history and lasted for a long time (9.5 months), until 17 October 1875 (Sigurdsson and Sparks, 1978). The eruption was characterized by pyroclastic flows, lava flows, caldera collapse and produced huge volumes of lava and tephra, about $0.3 \mathrm{~km}^{3}$ and $2 \mathrm{~km}^{3}$, respectively. The main explosive eruption $(\mathrm{VEI}=5)$ occurred on 28-29 March 1875 and lasted about $17 \mathrm{~h}$. The eruption expressed different types of activities such as subplinian, phreatoplinian (interaction of magma with water), pyroclastic surge and Plinian type, which in turn includes drastic variations in water vapor content as well as transitions from fall to flow activity (Carey et al., 2010). The eruption plume height during the Plinian phase rose to altitudes between 22 and $26 \mathrm{~km}$, according to different studies (Carey and Sparks, 1986; Pyle, 1989; Carey et al., 2010).

We briefly mentioned the major powerful eruptions which had distinct atmospheric disturbances, producing deep stratospheric (up to the mesosphere) injections of water vapor and aerosol particles. It is not excluded that some of these volcanic disasters could be a trigger for the formation of the earliest noctilucent clouds, which could be noted in astronomical reports from the 1700 s and 1800 s.

\section{The year of the earliest known observations of noctilucent clouds: 1884 or 1885 ?}

Now we shall discuss a new established year of the NLC discovery. In our opinion, it is better to refer to astronomers as the pioneers of the first NLC observations, these having been professional observers. It is likely that some of the below-mentioned statements were not read by contemporary researches primarily due to language barriers. Our aim is not to cite all available first descriptions of NLCs but rather to draw the reader's attention to what we consider to be the most important statements that should not be ignored when considering the year of the of NLC discovery. The question about 1884 or 1885 has certain importance in connection with possible Krakatao eruption influence.

The majority of papers, devoted to first observations of noctilucent clouds, refer not to 1884 but to 1885 as a year of first reliable descriptions undoubtedly concerning noctilucent clouds. Robert Charles Leslie was a British painter who did describe some twilight phenomenon in the popular scientific magazine Nature (London) in 1884, resembling noctilucent clouds: “...This was at times very remarkable in the early part of July this year, when we had some of the strangest white sunsets I have ever seen. The sky around and above where the sun had set, looking almost ceiling-like in its opacity, upon which soon appeared numbers of weird small cloud forms, at times very regular, like ripple-marks in sand, or the bones of some great fish or saurian embedded on a

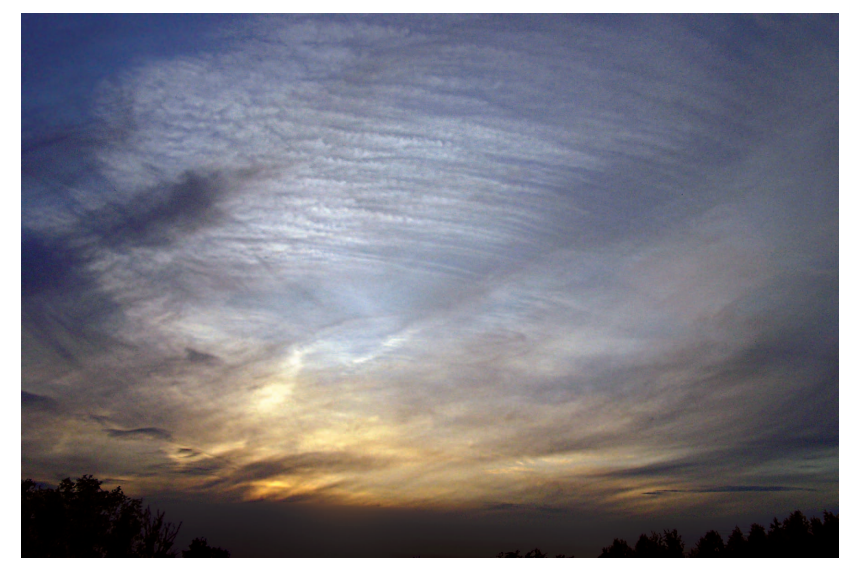

Figure 2. Photograph courtesy of A. O. Andreyev (Andreyev et al., 2007). High-altitude cirrus clouds look like noctilucent clouds in the evening hours.

slab of stone. Against these pale sunsets all buildings and trees told like black velvet, while the clouds would rest almost stationary for a long time. Years back such a sky would have betokened a hurricane; but evening after evening they were repeated, and no storm of any importance followed."

Indeed, this description resembles morphological forms (bands and billows according to the modern classification, Grishin, 1957) of NLCs. At the same time, it is a well-known observable fact that well-developed cirrus clouds have similar morphological forms, brightness and color and might be confused with NLCs in the evening and morning hours (see Figs. 2 and 3). Figures 2 and 3 demonstrate high-altitude cirrus in the evening and morning hours, which looks like NLCs and may be identified by an experienced observer in the course of a time only. Also, we should take into account abnormally colored (purple) twilights and optical disturbances during 1884 . The stratospheric clouds may appear at $14-15 \mathrm{~km}$ due to volcanic aerosols (Siebert et al., 2000), and they may look like bright cirrus clouds against the dark background sky during civil and early nautical twilight. The observation of Leslie during the 1884 "volcanic summer" may be attributed to rare and unusual (but sometimes observed) summer stratospheric clouds.

It is important to note that in his successive observations (in 1885 and 1886), Leslie devoted to the night luminous clouds as a new phenomenon, writing nothing about priority of that observation of 1884; moreover, he did not refer to it at all. Let us cite Leslie's observations of 1885 and 1886 to obtain as full a picture of his vision as possible:

Leslie (1885): "Ever since the sunsets of 1883 and last year there has been at times an abnormal glare both before and after sundown. But I have seen nothing in the way of twilight effect so strange as that of Monday evening, the 6th, when about 10 p.m. a sea of luminous silvery white cloud lay above a belt of ordinary clear twilight sky, which was 


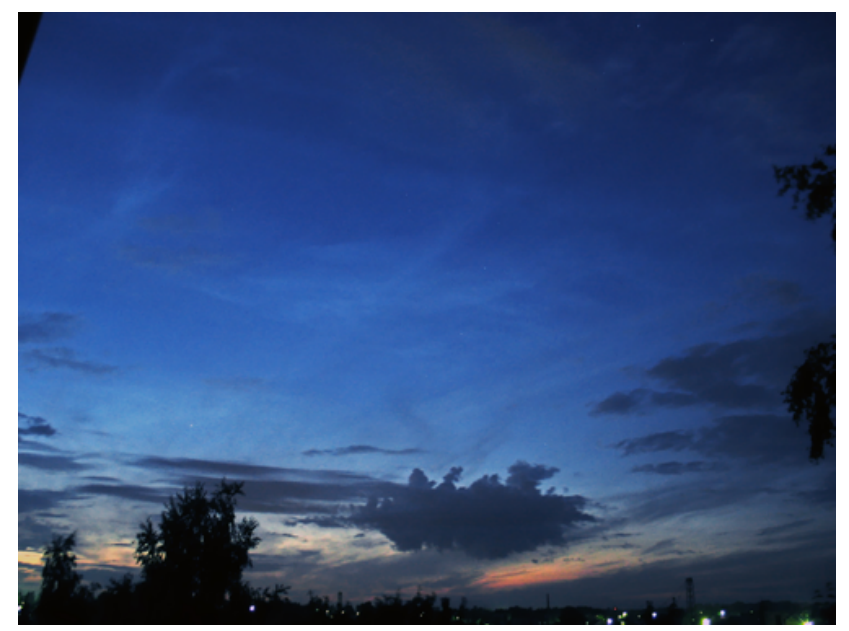

Figure 3. Photographed by P. Dalin. High-altitude cirrus clouds are very similar (by morphological forms, color and brightness) to noctilucent clouds in the morning hours.

rather low in tone and colour. These clouds were wave-like in form, and evidently at a great elevation, and though they must have received their light from the sun, it was not easy to think so, as upon the dark sky they looked brighter and paler than clouds under a full moon."

Leslie (1886): "I am not sure of the date, but believe it was in June 1885 that I called attention in your journal to a strange effect of bright silvery lighted clouds, which remained visible in the north-west sky after sunset until nearly 11 p.m. Several times this summer I have noted repetitions of these same curiously lighted cloud-forms, but have never seen such a wonderful display of this "after-sheen" as that of this evening, July 12."

Thus, the note of painter R. C. Leslie on the NLC observation of 1884 cannot be regarded as a reliable enough.

The German astronomer Otto Jesse wrote in his article (Jesse, 1888a): "I observed often, in the summer of 1884, the purple light and carried out a greater number of measurements on it. The phenomenon of noctilucent clouds would not therefore have escaped my attention if they were already visible at that time." (translated by W. Schröder, 2001). One can read one more important note made by O. Jesse in 1889: "The glowing night clouds have themselves since their first appearance in 1885 been repeated over Europe every year in the months June and July."

Another important observation is found in the memoirs of the Russian astronomer Vitold Tseraskii (Tseraskii, 1890, 1953) who wrote the following: “...I have been repeatedly objected that these clouds may have existed before 1885 but they were not noticed. As for me, I can say that I have been observing with a photometer since 1875, and I regard these observations are difficult and very unpleasant, solely due to special attention focused on the slightest cloud or a fine mist. It would be pretty hard for me to not notice the phenomenon which sometimes covers no more nor less than the entire vault of heaven."

Here it is appropriate to consider the following historical events. It is well-known from English-speaking literature that the earliest known photographs of NLCs were taken by O. Jesse and his colleagues F. Stolze and K. F. Küstner in 1887 (Jesse, 1887; Gadsden and Schröder, 1989). However, the Russian researcher Vitaly Bronsten managed to find an unpublished letter by V. Tseraskii, dated July of 1886, in astronomical archives of the Moscow University. The letter was written in German and was addressed to the "Astronomische Nachrichten" journal. It was dedicated to the first observations of noctilucent clouds and was a response to the appeal of O. Jesse to observe night clouds, published in "Astronomische Nachrichten" (Jesse, 1886a). V. Bronsten translated the letter of V. Tseraskii into Russian and published it in the Russian Historical-Astronomical Researches (Bronsten, 1975). Owning to V. Bronsten, we can read, in particular, the following important issue: "...However, it is obvious that starlight is partly absorbed and since these clouds appear for two summers, it is impossible to conduct astrophotometrical observation. Clouds can be easily photographed and the taken images are very striking. To determine directly the height of these clouds, we have defined their parallaxes from the two stations..." V. Bronsten fairly noticed (Bronsten, 1975, 1984), it is clear from these words that V. K. Tseraskii not only visually observed noctilucent clouds but also photographed them. Unfortunately, not a single one of Tseraskii's photographs of noctilucent clouds were found in either his archives or his articles. Since the abovementioned note was made in July of 1886 , it is evident that V. K. Tseraskii managed to photograph noctilucent clouds in 1885 or 1886 , that is, 1-2 yr before O. Jesse who owns the first published images of noctilucent clouds.

It is worth noting another historical fact on the earliest determinations of the height of noctilucent clouds. Otto Jesse first determined the height of noctilucent clouds on 19 July 1885; however, he made the measurement from a single site and hence the NLC height was approximately estimated at about $60 \mathrm{~km}$ (Jesse, 1885). The more accurate determination of the NLC height of about $75 \pm 5 \mathrm{~km}$ was made by O. Jesse on 6 July 1887, when he took his first NLC photographs together with his colleagues F. Stolze and K. F. Küstner from two stations in Berlin and Potsdam, separated by $23 \mathrm{~km}$ (Jesse, 1887). The most precise measurements were performed by O. Jesse in 1888-1891, when he conducted triangulation measurements from several stations and estimated the NLC height to be in the range of 80$88 \mathrm{~km}$, with the average altitude equal to $82.08 \pm 0.009 \mathrm{~km}$ (Jesse, 1896). At the same time, it is a well-known historical fact that on 26 June 1885, V. K. Tseraskii together with his colleague A. A. Belopolskii made five triangulation observations (by drawing the most striking NLC details and measuring their azimuthal and elevation angles with the Ertel theodolites) from two sites near Moscow separated by $32 \mathrm{~km}$ 
(Tseraski, 1887). One of their measurements of $52.3 \mathrm{~km}$ was certainly wrong and out of the statistical confidence level; the other four measurements lied in the range between 72.5 and $83.2 \mathrm{~km}$, with the average height value equal to $79.2 \mathrm{~km}$ (Tseraski, 1887; Bronsten, 1984), which is close to modern estimations of the height of noctilucent clouds. Thus, for the first time, on 26 June 1885, it was demonstrated that clouds may occur at very great altitudes in the Earth's atmosphere, far above the ordinary tropospheric clouds.

Here we return to the discussion on the earliest known observations of NLCs. Wilhelm Foerster (director of the Berlin Observatory) and Otto Jesse wrote in their article published in Nature in 1892: "Since the year 1885 a very remarkable phenomenon has been noticed in the sky in our latitudes, which well deserves to excite the interest of astronomers and geophysicists. The following is the substance of what has so far become known regarding the so-called luminous night-clouds...". It is important to know the following. O. Jesse cited Leslie's observation of 1885 in his article (Jesse, 1886b), as well as, mentioned the observations of V. Tseraskii of 1885 and 1888 (Jesse, 1887, 1888b). Thus, O. Jesse was aware of the current state of observations of a new night shining phenomenon both in Western and Eastern Europe. However, O. Jesse did not refer to the questionable observation of R. Leslie of 1884 in any of his articles.

A famous historical researcher Wilfried Schröder (1999), who spent many years studying archival material on noctilucent clouds, made note in his article: "It seems very unlikely that experienced observers such as Riggenbach, Bezold, Hellmann, Kiessling and Jesse would have overlooked such striking phenomena as noctilucent clouds. Moreover, Jesse (1886) made systematic twilight observations during the years before 1885. He noted that if there had been noctilucent clouds, he would not have overlooked them. Furthermore, in all the descriptions by the cited observers no remarks are given that show any references to what could have been noctilucent clouds. From the data presented here it can be concluded that noctilucent clouds were not observed before 1885 ( $c f$. Table 4)."

Thus, it is evident that many professional observers in Europe and Russia conducted regular summer observations of the night sky prior to 1885 , but none of the above researchers marked any signatures of night luminous clouds.

Summarizing, one should consider two important notes. Fogle and Haurwitz (1966) mentioned in their comprehensive review on the NLC studies: "The first recorded recognition of observed clouds as being an unusual phenomenon in respect of height was made by $T$. W. Backhouse (1885) at Kissingen, Germany on June 8 of that year. Doubtless such clouds had been noticed earlier, but the published accounts are not sufficiently definite for them to be identified certainly as NLC (see Arago, 1854; Scultetus 1949)."

And, Gadsden and Schröder (1989) wrote in their canonical book: "...It is certain that at the times of coloured twilight appearances of 1883/1884, no noctilucent clouds were discovered. Various reports also exist which could be interpreted as noctilucent clouds, but this will always remain uncertain (Pernter 1889; Schröder 1975; Gadsden 1985)”.

\section{Conclusions}

1. The observation of British painter Robert Leslie made in 1884 might correspond to not only NLCs but also to cirrus and volcanic stratospheric clouds. Certain additional arguments confirm this opinion. So, it is not worth to mention 1884 as a doubtless year of the earliest known observations of NLCs. For those researchers who are adamantly set to consider 1884 as the year of the discovery of noctilucent clouds, we suggest finding a compromise. If someone wants to specify 1884 , she/he can indicate it in the manner similar to the following: the first appearance of clouds resembling NLCs was noted at a single site (in the United Kingdom) only and by the only observer-enthusiast (Leslie, 1884) (and in this case, please do not forget to mention another candidate to be the first NLC observer - the great Russian poet Alexander Pushkin); however, bright and extensive noctilucent clouds were observed and described by many observers-enthusiasts as well as by astronomers over a huge territory from Western Europe to Russia for many nights in June and July of 1885.

2. The 1883 Krakatoa eruption is thought to be not the only and not the most powerful trigger for the appearance of NLCs. There were slightly less (Laki in 1783, Mount St. Helens in 1800, Galunggung in 1822, Cosigüina in 1835, Shiveluch in 1854 and Askja in 1875) and even greater volcanic eruptions, such as Tambora in 1815, in recorded history. These great explosive eruptions had pronounced effects on the lower atmosphere (regionally and globally) and could have great consequences on the mesosphere as well, supplying significant amounts of water vapor and aerosols and thus fostering the NLC formation, which could exist for short time intervals in summers after major volcanic eruptions. When analyzing volcanic activity as a possible trigger for the earliest observations of noctilucent clouds, it is important to consider a significant eruption of the Augustine volcano occurred in October of 1883, along with the great 1883 Krakatoa eruption, which could supply the subpolar and polar mesosphere with significant amounts of water vapor and aerosols.

3. The first reliable height estimations of NLCs were made by the Russian astronomers V. K. Tseraskii and A. A. Belopolskii on 26 June 1885, who estimated the altitude of noctilucent clouds being in the range of $73-83 \mathrm{~km}$. V. K. Tseraskii took the first photographs of NLCs in 1885 or 1886, 1-2 yr before the German astronomer O. Jesse who owns the first published 
images of noctilucent clouds. Unfortunately, not one photograph of noctilucent clouds was found in either Tseraskii's papers or his archives.

\section{Further research}

It is not excluded that some of the abovementioned volcanic disasters had influence not only on the lower atmosphere but also on the middle atmosphere as Krakatoa did. We want to request to those researchers who have access to archives of astronomical observations for 1784-1785, 1800-1801, $1809-1817$, 1823-1824, 1835-1836, 1854-1855, 18751876 to look carefully at the summer observations for these years. NLCs might have appeared especially during these periods, $1 / 2-2 \mathrm{yr}$ after the greatest volcanic eruptions during the period of $1783-1883$.

Besides, we have to keep in mind that other potential sources of information such as diaries of farmers, large land owners, military people, might include descriptions resembling noctilucent clouds, which are worth searching through for the above-mentioned periods.

Acknowledgements. The paper benefited from constructive comments and suggestions made by one anonymous reviewer and Topical Editor Hans Volkert. The authors gratefully acknowledge Irina Strelnikova for providing copies of publications of Otto Jesse, and Peter Völger for his assistance in translation of those materials. Thanks are due to Lisa Holmström for the English editing.

Edited by: H. Volkert

Reviewed by: K. C. Harper

\section{References}

Andreyev, A. O., Dukalskaya, M. V., and Golovina, E. G.: Clouds: origin, classification, identification, Sankt-Peterburg, Izd. RGGMU, 228 pp., 2007 (in Russian).

Becker, E. and Schmitz, G.: Climatological Effects of Orography and Land-Sea Heating Contrasts on the Gravity Wave-Driven Circulation of the Mesosphere, J. Atmos. Sci., 60, 103-118, 2003.

Björnsson, E.: Relation by one priest, who traveled in the summer 1783 to Southern Iceland from Múlasysla county through Skaftafellssysla county back and forth, in: Skaftáreldar 17831784: Ritgerdir og heimildir, edited by: Gunnlaugsson, G. A. and Rafnsson, S., Mál og Menning, Reykjavik, 295-297, 1783 (in Icelandic).

Braitseva, O. A., Sulerzhitsky, L. D., Ponomareva, V. V., and Melekestsev, I. V.: Geochronology of the greatest Holocene explosive eruptions in Kamchatka and their imprint on the Greenland glacier shield, Dokl. Earth Sci., 352, 138-140, 1997 (in Russian).

Briffa, K. R., Jones, P. D., Schweingruber, F. H., and Osborn, T. J.: Influence of volcanic eruptions on Northern Hemisphere summer temperature over 600 years, Nature, 393, 450-455, doi:10.1038/30943, 1998.
Bronsten, V. A.: Neopublikovannye nabludenia serebristyx oblakov V.K. Tseraskogo (Unpublished observations of noctilucent clouds of V.K. Tseraskii), Istoriko-Astronomicheskie Issledovania, edited by: Maystrov, L. E., Nauka, Moscow, 12, 385-389, 1975 (in Russian).

Bronsten, V. A.: Noctilucent clouds and their observations, Nauka, Moscow, 128 pp., 1984 (in Russian).

Bronsten, V. A. and Grishin, N. I.: Noctilucent clouds, Moscow, Nauka, 359 pp., 1970 (in Russian).

Carey, R. J., Houghton, B. F., and Thordarson, T.: Tephra dispersal and eruption dynamics of wet and dry phases of the 1875 eruption of Askja volcano, Iceland, Bull. Volcanol., 72, 259-278, doi:10.1007/s00445-009-0317-3, 2010.

Carey, S. N. and Sparks, R. S. J.: Quantitative models of fallout and dispersal of tephra from volcanic eruption columns, Bull. Volcanol., 48, 109-125, 1986.

Carey, S., Gardner, J., and Sigurdsson, H.: The intensity and magnitude of Holocene plinian eruptions from Mount St. Helens volcano, J. Volcanol. Geotherm. Res., 66, 185-202, 1995.

Ceraski, W. (Tseraskii, V.): Sur les nuages lumineux, Annales de l'Observatoire de Moscou, Series II, Vol. II, 177-180, 1890 (in French).

Cole-Dai, J., Ferris, D., Lanciki, A., Savarino, J., Baroni, M., and Thiemens, M. H.: Cold decade (AD 18101819) caused by Tambora (1815) and another (1809) stratospheric volcanic eruption, Geophys. Res. Lett., 36, L22703, doi:10.1029/2009GL040882, 2009.

Crandell, D. R., Mullineaux, D. R., and Rubin, M.: Mount St. Helens volcano: recent and future behavior, Science, 187, 4175, 438-441, 1975.

Foerster, W. and Jesse, O.: Invitation to observe the luminous night clouds, Nature, 46, 589-590, 1892.

Fogle, B. and Haurwitz, B.: Noctilucent clouds, Space Sci. Rev., 6, 279-340, 1966.

Fogle, B. and Haurwitz, B.: Long term variations in noctilucent cloud activity and their possible cause, Climatological Research, edited by: Fraedrich, K., Hantel, M., Claussen Korf, H., and Ruprecht, E., Bonner Meteorologische Abhandlungen, Bonn, Germany, 263-276, 1973.

Franklin, B.: Meteorological imaginations and conjectures, In Mem. Lit. Philos. Soc. Manchester, 2, 373-377, 1784.

Gadsden, M. and Schröder, W.: Noctilucent Clouds, Springer, New York, 165 pp., 1989.

Galindo, J.: Eruption of the volcano Cosiguina, Am. J. Sci., 28, 332-336, 1835a.

Galindo, J.: On the eruption of the volcano Cosigüina, in Nicaragua, Journal of the Royal Geographical Society of London, 5, 387392, $1835 b$.

Gorshkov, G. S and Dubik, Yu. M.: Gigantic directed blast at Shiveluch volcano (Kamchatka), Bull. Volcanol., 34, 261-288, 1970.

Grishin, N. I.: Instructions for noctilucent cloud observations, Izdatelstvo Akad. Nauk SSSR, Moscow, 23 pp., 1957 (in Russian).

Hartquist, T., Havnes, O., and Kassa, M.: Exploring polar mesospheric summer echoes, Astron. Geophys., 50, 1.8-1.14, doi:10.1111/j.1468-4004.2009.50108.x, 2009.

Jensen, E. and Thomas, G. E.: A growth-sedimentation model of polar mesospheric clouds: comparisons with SME measurements, J. Geophys. Res., 93, 2461-2473, 1988.

Jesse, O.: Auffallende Abenderscheinungen am Himmel, Meteorol. 
Z., 2, 311-312, 1885 (in German).

Jesse, O.: Aufforderung betreffend Beobachtungen der glänzenden Himmelserscheinungen, welche seit dem Sommer 1885 öfter in Mittel-Europa gesehen worden sind, Astron. Nachr., 2737, 1516, 1886a (in German).

Jesse, O.: Die auffallenden Abenderscheinungen am Himmel im Juni und Juli 1885, Meteorol. Z., 2, 8-18, 1886b (in German).

Jesse, O.: Die Höhe der leuchtenden (silbernen) Wolken, Meteorol. Z., 4, p. 424, 1887 (in German).

Jesse, O.: Ueber die leuchtenden (silbernen) Wolken, Meteorol. Z., 5, 90-94, 1888a (in German).

Jesse, O.: Leuchtenden Wolken, Meteorol. Z., 5, p. 369, 1888b (in German).

Jesse, O.: Die leuchtenden Nachtwolken, Meteorol. Z., 6, 184-186, 1889 (in German).

Jesse, O.: Die Höhe der leuchtenden Nachtwolken, Astron. Nachr., 140, 161-168, 1896 (in German).

Leslie, R.: The sky-glows, Nature, 30, p. 583, 1884.

Leslie, R.: Sky glow, Nature, 32, p. 245, 1885.

Leslie, R.: Luminous clouds, Nature, 34, p. 264, 1886.

Meniailov, A. A.: Shiveluch volcano: geological structure, composition of products and eruptions, Trans Laboratory of Volcanology, USSR Academy of Sciences, 9, 265 pp., 1955 (in Russian).

Mullineaux, D.: Summary of pre-1980 tephra fall deposits erupted from Mount St. Helens, Washington state, USA, Bull. Volcanol., 48, 17-26, 1986.

Newhall, C. G. and Self, S.: The Volcanic Explosivity Index (VEI): an estimate of explosive magnitude for historical volcanism, J. Geophys. Res., 87, 1231-1238, 1982.

Oppenheimer, C.: Climatic, environmental and human consequences of the largest known historic eruption: Tambora volcano (Indonesia) 1815, Prog. Phys. Geog., 27, 230-259, doi:10.1191/0309133303pp379ra, 2003.

Pautet, P.-D., Stegman, J., Wrasse, C. M., Nielsen, K., Takahashi, H., Taylor, M. J., Hoppel, K. W., and Eckermann, S. D.: Analysis of gravity waves structures visible in noctilucent cloud images, J. Atmos. Sol.-Terr. Phy., 73, 2082-2090, doi:10.1016/j.jastp.2010.06.001, 2011.

Ponomareva, V. V., Pevzner, M. M., and Melekestsev, I. V.: Large debris avalanches and associated eruptions in the Holocene eruptive history of Shiveluch volcano, Kamchatka, Russia, Bull. Volcanol., 59, 490-505, 1998.

Pyle, D. M.: The thickness, volume and grain-size of tephra fall deposits, Bull. Volcanol., 51, 1-15, 1989.

Raffles, S.: Memoir of the life and public services of Sir Thomas Stamford Raffles, F.R.S. \&c., particularly in the government of Java 1811-1816, and of Bencoolen and its dependencies 18171824: with details of the commerce and resources of the eastern archipelago, and selections from his correspondence, London, John Murray, 1830.

Rampino, M. and Self, S.: Historic eruptions of Tambora (1815), Krakatau (1883) and Agung (1963), their stratospheric aerosols and climatic impact, Quaternary Res., 18, 127-143, 1982.

Schröder, W.: Were noctilucent clouds caused by the Krakatoa eruption? A case study of the research problems before 1885, B. Am. Meteorol. Soc., 80, 10, 2081-2085, 1999.

Schröder, W.: Otto Jesse and the investigation of noctilucent clouds 115 years ago, B. Am. Meteorol. Soc., 82, 2457-2468, 2001.

Scott, W., Gardner, C., Devoli, G., and Alvarez, A.: The A.D. 1835 eruption of volcan Cosigüina, Nicaragua: a guide for assessing local hazards, in: Volcanic hazards in Central America, edited by: Rose, W. I., Bluth, G. J. S., Carr, M. J., Esert, J. W., Patino L. C., and Vallance, J. W., Geol. Soc. Amer. Spec. Pap., 412, 167-187, 2006.

Self, S. and Rampino, M.: The 1883 eruption of Krakatau, Nature, 294, 699-704, 1981.

Self, S., Rampino, M. R., and Carr, M. J.: A reappraisal of the 1835 eruption of Cosigüina and its atmospheric impact, Bull. Volcanol., 52, 57-65, 1989.

Shelley, M.: Frankenstein; or, The Modern Prometheus, edited by: Curran, S., Colburn, H., and Bentley, R., London, 1831.

Siebert, J., Timmis, C., Vaughan, G., and Fricke, K. H.: Letter to the Editor: A strange cloud in the Arctic summer stratosphere 1998 above Esrange $\left(68^{\circ} \mathrm{N}\right)$, Sweden, Ann. Geophys., 18, 505-509, doi:10.1007/s00585-000-0505-0, 2000.

Siebert, L., Simkin, T., and Kimberly, P.: Volcanoes of the World, Third Edn., University of California Press, Los Angeles, 551 pp., 2010.

Sigurdsson, H. and Carey, S.: Plinian and co-ignimbrite tephra fall from the 1815 eruption of Tambora volcano, Bull. Volcanol., 51, 243-270, 1989.

Sigurdsson, H. and Sparks, R. S. J.: Rifting episode in North Iceland in 1874-1875 and the eruptions of Askja and Sveinagja, Bull. Volcanol., 41, 149-167, 1978.

Sigurdsson, H., Carey, S., Mandeville, C., and Bronto, S.: Krakatau volcano expedition 1990, Report to the National Geographic Society, 37 pp., 1990.

Solomina, O., Pavlova, I., Curtis, A., Jacoby, G., Ponomareva, V., and Pevzner, M.: Constraining recent Shiveluch volcano eruptions (Kamchatka, Russia) by means of dendrochronology, Nat. Hazards Earth Syst. Sci., 8, 1083-1097, doi:10.5194/nhess-81083-2008, 2008.

Steingrímsson, J. and Ólafsson, S.: A simple, but true narrative of the eruption in Skaftafell county in the year 1783, dated November 241788 at Kirkjubæjarklaustur. Safn til Sögu Islands, IV, Copenhagen, 1907-1915, 58-69, 1783 (in Icelandic).

Stephensen, O.: Abstract from O. Stephensen's letter to J. Eiriksson, dated August 25, 1783, in: Skaftáreldar 1783-1784: Ritgerdir og heimildir, edited by: Gunnlaugsson, G. A. and Rafnsson, S., Mál og Menning, Reykjavfk, 1984, p. 279, 1783 (in Icelandic).

Stewart, G. A.: Description of a volcanic eruption in the island of Sumbawa, Edinburgh Philosophical Journal, 3, 398-392, 1820.

Stothers, R. B.: The great Tambora eruption in 1815 and its aftermath, Science, 224, 1191-1198, doi:10.1126/science.224.4654.1191, 1984.

Sunstein, E. W.: Mary Shelley: Romance and Reality, Baltimore, Johns Hopkins University Press, 514 pp., 1991.

Symonds, R. B., Rose, W. I., Bluth, G., and Gerlach, T. M.: Volcanic gas studies: methods, results, and applications, in: Volatiles in Magmas: Mineralogical Society of America Reviews in Mineralogy, edited by: Carroll, M. R. and Holloway, J. R., 30, 1-66, 1994.

Taylor, M. J., Gadsden, M., Lowe, R. P., Zalcik, M. S., and Brausch, J.: Mesospheric cloud observations at unusually low latitudes, J. Atmos. Sol.-Terr. Phy., 64, 991-999, 2002.

Thomas, G. E., Olivero, J. J., Jensen, E. J., Schroeder, W., and Toon, O. B.: Relation between increasing methane and the presence of 
ice clouds at the mesopause, Nature, 338, 490-492, 1989.

Thorarinsson, Á.: Reverend Thorarensen's documentation, in: Skaftáreldar 1783-1784: Ritgerdir og heimildir, edited by: Gunnlaugsson, G. A. and Rafnsson, S., Mál og Menning, Reykjavik, 1984, 280-283, 1783 (in Danish).

Thordarson, T. and Self, S.: The Laki (Skaftár Fires) and Grímsvötn eruptions in 1783-1785, Bull. Volcanol., 55, 233-263, 1993.

Thordarson, T., Self, S., Oskarsson, N., and Hulsebosch, T.: Sulfur, chlorine, and fluorine degassing and atmospheric loading by the 1783-1784 AD Laki (Skaftár Fires) eruption in Iceland, Bull. Volcanol., 58, 205-225, 1996.

Thordarson, T. and Self, S.: Atmospheric and environmental effects of the 1783-1784 Laki eruption: a review and reassessment, J. Geophys. Res., 108, 4011, doi:10.1029/2001JD002042, 2003.

Tseraskii, V. K.: Astronomichesky fotometr i ego prilozhenia (Astronomical photometer and its applications), Doctoral Dissertation, Mathematical Proceedings, XIII, Section 21, 626-631, 1887 (in Russian).

Tseraskii, V. K.: Luminous clouds, in: book "V. K. Tseraskii. Izbrannye raboty po astronomii", edited by: Podobed, V. V., Gostehizdat, Moscow, 81-84, 1953 (in Russian).

Verbeek, R. D. M.: The Krakatau eruption, Nature (London), 30, $10-15,1884$.
Wood, C. A.: Climatic effects of the 1783 Laki eruption, in: The Year Without a Summer?, edited by: Harington, C. R., Canadian Museum of Nature, Ottawa, 58-77, 1992.

Williams, H.: The great eruption of Coseguina, Nicaragua, in 1835 , University of California Publications in Geological Sciences, 29, 21-46, 1952.

Wilson, L. and Walker, G. P. L.: Explosive volcanic eruptions VI: ejecta dispersal in plinian eruptions: the control of eruption conditions and atmospheric properties, Geophys. J. Roy. Astr. S., 89, 651-679, 1987.

Yamaguchi, D.: New tree-ring dates for recent eruptions of Mount St. Helens, Quaternary Res., 20, 246-250, 1983.

Zielinski, G. A., Mayewski, P. A., Meeker, L. D., Whitlow, S., Twickler, M. S., Morrison, M., Meese, D. A., Gow, A. J., and Alley, R. B.: Record of Volcanism since 7000 BC from the GISP2 Greenland Ice Core and implications for the Volcano-Climate System, Science, 264, 948-952, 1994.

Zollinger, H.: Besteigung des Vulkans Tamboro auf der Insel Sumbawa und Schilderung der Eruption desselben im Jahre 1815, Wintherthur: Zurcher and Fürber, Wurster and Co., 1-21, 1855. 